\title{
ОСОБЛИВОСТІ ПІДГОТОВКИ МЕДИЧНИХ СЕСТЕР 3 ПАЛІАТИВНОЇ ТА ХОСПІСНОЇ ДОПОМОГИ В УКРАЇНІ ТА ПОЛЬЩІ
}

\author{
Н. А. Бугаєвська, Н. І. Рега \\ Комунальний заклад “Бериславський медичний коледж» Херсонської обласної ради \\ ДВНЗ «Тернопільський державний медичний університет \\ імені І. Я. Горбачевського МОз Украӥни»
}

Предмет «Паліативна медицина» охоплює засвоєння комплексу медичних, соціальних, психологічних та духовних заходів, спрямованих на поліпшення якості життя пацієнтів, які мають невиліковну хворобу та обмежений прогноз життя, а також членів їхніх сімей. У статті проведено аналіз підготовки магістрів медсестринства. Порівняно особливості викладання паліативної медицини в Україні та Польщі.

\section{FEATURES TRAINING OF NURSES ON PALIATIVE AND HOSPISE CARE IN UKRAINE AND POLAND}

\author{
N. A. Buhaievska, N. I. Reha \\ Beryslav Medical College \\ I. Horbachevsky Ternopil State Medical University
}

\begin{abstract}
The subject Palliative Medicine includes the mastering of complex medical, social, psychological and spiritual activities aimed at improving the quality of life of patients with terminal illness and the limited outlook of life and their family members. Analysis of the master of nursing training in health education is performed in the article. The features of teaching Palliative Medicine in Ukraine and Poland is compared.
\end{abstract}

Вступ. Проблеми інтеграції України в Європейський простір є актуальними та вкрай потрібними нашій країні [18]. У контексті євроінтеграції наша країна вже багато років співпрацює з багатьма країнами світу з питань реформування та модернізації медсестринської освіти, використовуючи їх позитивний досвід у підготовці медичних сестер, а також впровадженні в практичну медицину нової медсестринської моделі [1, $5,8,9]$. Цим питанням приділяють багато уваги [1, 5, 8].

Вже багато років в Україні питанням підготовки медичних сестер, бакалаврів та магістрів медсестринства опікуються такі фахівці, як Т. І. Чернишенко (директор Державної установи «Центральний методичний кабінет підготовки молодших спеціалістів» МОЗ України), С. О. Ястремська (директор ННІ медсестринства ДВНЗ «Тернопільський державний медичний університет імені І. Я. Горбачевського МОЗ України»), В. Й. Шатило (ректор), П. В. Яворський (Житомирський інститут медсестринства), М. Б. Шегедин (директор Львівського

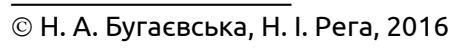

державного медичного коледжу ім. Андрея Крупинського), І. Я. Губенко (директор), І. В. Радзієвська, л. П. Бразалій (Черкаський медичний коледж).

Сьогодення вимагає впровадження в навчальний процес та в сферу соціальних змін в Україні питань створення та розвитку паліативної допомоги. В Україні, як і в більшості країн Європи та світу, постійно зростає відсоток старших людей, пацієнтів (як дорослих, так і дітей) із тяжкими, невиліковними хворобами, які потребують цілодобового догляду та спеціальної хоспісної допомоги [1, 9]. Кількість хоспісів у країні недостатня, знань та практичних навичок, необхідних ліків, медичного спорядження та засобів медичного та санітарного догляду хронічно не вистачає, бракує кваліфікованих лікарських та медсестринських кадрів [8]. Все це потребує кардинальних змін як у мисленні влади та керівництва медичної галузі, так і самого суспільства до проблеми паліативної та хоспісної медицини. Потрібні нові хоспіси (будови, забезпеченість кадрами та оснащенням), потребують змін навчаль- 
ні програми [8]. Виникла необхідність виділення в окремі дисципліни таких предметів, як «Геріатрія та геронтологія», «Паліативна та хоспісна медицина». Це потребує введення додаткових навчальних годин як на додипломному етапі, так і в системі післядипломної освіти [8]. Для того, щоб все це втілити в життя, потрібно активніше вивчати європейський та світовий досвід як у навчальному процесі, так і в практичній діяльності. Тому досвід Польщі серед інших країн-сусідів України в підготовці медичних сестер та їх подальшої праці в закладах паліативно-хоспісної допомоги є безцінним для нашої країни.

Основна частина. Як в Україні, так і в Польщі питання, пов'язані з наданням допомоги, спілкуванням та доглядом за невиліковно хворими пацієнтами, студенти медичних училищ та коледжів починають вивчати на старших курсах додипломного навчання. Це зумовлено тим, що викладання питань паліативної та хоспісної допомоги потребує попереднього вивчення ряду клінічних та допоміжних дисциплін, що дозволить розуміти та засвоювати питання, пов'язані з проблемами та потребами вмираючих пацієнтів. Без знань основ медсестринства, догляду за хворими, маніпуляційної техніки, етики та деонтології, медичної психології та основ міжособистісного спілкування, медсестринства в онкології та ряду інших дисциплін важко було $б$ уявити засвоєння майбутніми медсестрами паліативної та хоспісної допомоги. Особливістю вивчення питань, пов'язаних із паліативно-хоспісною допомогою в системі додипломної медсестринської освіти, на відміну від їх вивчення польськими студентами медсестринського відділення $\epsilon$ те, що українські студенти вивчають цю дисципліну окремо, як в Польщі, тільки при здобутті магістерського рівня [10]. У нашій країні вивчення цієї дисципліни проводиться на II-III курсах відповідно до навчальних програм, які були підготовлені в 2011 р. фахівцями Черкаського базового медичного коледжу, зі спеціальностей: 5.12010102 «Сестринська справа» - для студентів медичних ВНЗ І-ІІ рівнів акредитації та 6.120101 «Сестринська справа» для бакалаврів, які навчаються в медичних ВН3 III рівня акредитації та інститутах медсестринства [3]. Зокрема, навчальна програма «Медсестринство в геронтології, геріатрії та паліативній медицині» для підготовки медичних сестер у медичних навчальних закладах I-III рівнів акредитації [3] підготовлена та введена в навчальний процес у 2011 р. авторським колективом викладачів Львівського державного медичного коледжу ім. Андрея
Крупинського (директор - доктор медичних наук, професор, заслужений лікар України М. Б. Шегедин) за участю провідного викладача Черкаського базового медичного коледжу І. В. Радзієвської. Ця програма передбачає загалом 81 навчальну годину, з яких питання з паліативної та хоспісної допомоги винесені в окремий розділ «Основи паліативної медицини» [3]. Даний розділ передбачає для вивчення 31 академічну годину, з яких виділено 21 годину на практичні заняття та 10 годин на самостійну роботу студентів. Теоретичні (лекційні) години цією програмою не передбачені [3]. При підготовці медсестер-магістрів у 2015 р. було розроблено та запроваджено в навчальний процес Робочу програму «Паліативна медицина». Галузь знань 22 «Охорона здоров'я», розробник: С. О. Ястремська, директор ННІ медсестринства ДВНЗ «Тернопільський державний медичний університет імені І. Я. Горбачевського МОЗ України». Ця програма передбачає загальну кількість годин - 180, з них лекцій - 12 годин, практичних занять - 48 годин, самостійна робота - 120 годин [6].

Що стосується питань післядипломної підготовки медичних сестер, то тут підготовка медичних сестер лПз проводиться згідно з «Програмою теоретичного удосконалення для медичних сестер первинної медико-санітарної допомоги», підготовленою в 2011 р. провідними фахівцями Черкаського базового коледжу [2]. В 2011 р. Державною установою «Центральний методичний кабінет підготовки молодших спеціалістів» МОЗ України (директор Т. І. Чернишенко) було впроваджено в навчальний процес програму циклу спеціалізації «Медсестринство в паліативній і хоспісній допомозі» для слухачів відділень післядипломної освіти, розроблену авторським колективом Черкаського базового медичного коледжу (директор І. Я. Губенко) $[2,4]$. Згідно з цією програмою всього передбачено 288 годин, з яких на лекції відведено 252 години, на самостійну роботу - 36 годин [2]. Ця програма передбачає 40 годин викладання теоретичного матеріалу (лекцій). Окрім психологічних та правових моментів, пов'язаних із наданням паліативно-хоспісної допомоги, наголошено на питаннях «Паліативна допомога при синдромі хронічного болю» - 12 годин та «Паліативна допомога інкурабельним онкологічним хворим» - 16 годин [2]. Для покращення та удосконалення викладання питань паліативної допомоги студентам-медсестрам у 2011 р. був впроваджений «Тематичний план і програма курсів удосконалення викладачів основ медсестринства ВМ(Ф)Н3 I-ІІІ рівнів акредитації (очно-заочна форма навчання)» [7]. 
В ньому передбачено по 12 теоретичних годин для вивчення таких важливих тем, як «Особливості здійснення медсестринського процесу в геріатричній клініці» та «Медсестринство в паліативній та хоспісній допомозі» [7].

Що стосується підготовки медичних сестер у Польщі з питань надання паліативно-хоспісної допомоги на додипломному та післядипломному етапах навчання, то тут $\epsilon$ свої особливості. В Польщі існує така система отримання медсестринської освіти [10]:

- Бакалаврське навчання - очне та заочне (3 роки), або навчання І рівня вищої освіти (не коротше 6 семестрів). Загальна кількість годин навчання - 4815, з них 2408 практичних годин та не менше 180 пунктів за системою ECTS. Після закінчення навчання випускник отримує титул бакалавра.

- Магістерське навчання - очне та заочне (2 роки), або навчання II рівня вищої освіти (не коротше 4 семестрів). Загальна кількість годин навчання - 1300 та не менше 120 пунктів за системою ECTS. Після закінчення навчання випускник отримує титул магістра.

- Докторантське навчання.

- Післядипломна освіта (очна та заочна).

Після отримання диплома бакалавра чи магістра медсестринства кожен випускник проходить 12-місячне післядипломне стажування в закладі медичного догляду за пацієнтами [10]. Тільки після цього окружна спілка медичних сестер та акушерів може направити його на стажування більш вищого рівня [10].

Під час навчання для отримання титулу бакалавра (рівень I ступеня) і магістра (рівень ІІ ступеня), згідно з розпорядженням міністра науки та вищої освіти щодо питання стандартів навчання (Rozporządzenie Ministra Nauki i Szkolnictwa Wyższego z dnia 9 maja 2012 r. (Dz. U. 631) w sprawie standardów kształcenia), польські студенти, окрім інших дисциплін, вивчають також такий предмет (дисципліну), як «Паліативна медицина». На його вивчення на I-ІІ рівнях навчальною програмою відведено по 95 годин, з них 15 теорії, по 40 годин відведено на практичні заняття [10].

Післядипломна освіта має такий розподіл: спеціалізоване навчання, курси кваліфікаційні, курси спеціалізації та курси додаткового удосконалення [10]. Після закінчення дворічного спеціалізованого навчання медична сестра отримує кваліфікацію в окресленому напрямку та титул спеціаліста в ньому. Інша форма навчання - це кваліфікаційні курси, які дають можливість отримати спеціальну кваліфікацію з виконання окремих медичних маніпуляцій [10]. Спе- ціалізовані курси дають спеціалізацію для виконання вузько окреслених, специфічних медичних, у т. ч. і медсестринських маніпуляцій (перитонеальний та нирковий діаліз, стома, інсулінова помпа тощо) [10]. В той же час курси додаткового навчання поглиблюють та актуалізують знання як з медсестринського фаху в цілому, так і з спеціалізації та вузькофахової направленості роботи медичної сестри [10]. Післядипломне навчання в Польщі може проводитися як стаціонарно, так і заочно [10]. Так, зокрема, відповідно до нових (2015 р.) навчальних програм, у післядипломній освіті існує 20 напрямків спеціалізації для медичних сестер. Три з них стосуються питань догляду за людьми похилого віку та тяжкохворими пацієнтами [10]. Це - медсестринський догляд у геріатрії (pięliegniarstwo opieki geriartycznrej), довготривалий догляд за тяжкохворими пацієнтами (Pielęgniarstwo opieki długoterminowej) та медсестринський паліативний догляд (Pielęgniarstwo opieki paliatywnej) [10]. Ця спеціалізація триває 2 роки та містить таку кількість годин навчання:

- Медсестринство в геріатрії - 990 годин, з них 580 теоретичних, 245 практичних годин та 165 годин на самостійну підготовку [13].

- Медсестринство довготривалого догляду за тяжкохворими в стаціонарних та домашніх умовах 967 годин, з них - 617 теоретичних, 350 практичних та 193 години на самостійну підготовку [12].

- Медсестринство в паліативному догляді - 960 годин, з них - 485 теоретичних, 315 практичних та 160 годин на самостійну підготовку [11].

До цього переліку можна сміливо додати четвертий напрямок - медсестринський догляд в онкології (pięliegniarstwo opieki onkologicznej) [14]. Спеціалізація медичної сестри з цього напрямку становить навчання з кількістю загальних годин - 960, з них: 485 теоретичних, 315 практичних годин та 160 годин на самостійну підготовку, так само, як і при спеціалізації медичних сестер із паліативної допомоги [14].

Окрім того, кваліфікаційний курс з паліативнохоспісного медсестринського догляду становить 456 навчальних годин. 3 них - 205 теоретичних годин, 175 практичних годин та 76 годин для самостійної підготовки. До нього входять базовий курс паліативної допомоги та педіатричний домашній паліативний догляд [11]. Кваліфікаційний курс із медсестринства в геріатрії становить 366 годин, з них - 180 теоретичних годин, 125 практичних та 61 година на самостійну підготовку [13]. Кваліфікаційний курс із довготривалого 
медсестринського догляду за тяжкохворими пацієнтами, в стаціонарних та домашніх умовах, становить 360 годин, з них - 164 теоретичних, 196 практичних та 72 години на самостійну підготовку [12].

Висновки. 1. При підготовці медичних сестер в Україні необхідне вивчення курсу паліативної та хоспісної допомоги, виділеного в окрему дисципліну, як на додипломному, так і післядипломному етапах підготовки.

\section{ЛІТЕРАТУРА}

1. Бразалій Л. П. Професійна підготовка медичних сестер з питань надання паліативної і хоспісної допомоги у Черкаському медичному коледжі / Л. П. Бразалій // Міжнародний журнал «Реабілітація та паліативна медицина». 2016. - № 1 (3). - С. 45-48.

2. Губенко І. Я. Медсестринство в паліативній і хоспісній допомозі : програма циклу спеціалізації для слухачів відділень післядипломної освіти / І. Я. Губенко, І. В. Радзієвська, Л. П. Бразалій. - К. : Медицина. - 2011. - 12 с.

3. Медсестринство в геронтології, геріатрії та паліативній медицині : програма для ВМ(Ф)НЗ І-ІІІ рівнів акредитації за спеціальністю 5.12010102 «Сестринська справа» / уклад. М. Б. Шегедин та ін. - К., 2011.

4. Мішуренко О. В. Досвід післядипломної підготовки медичних сестер з питань надання паліативної та хоспісної допомоги / О. В. Мішуренко, Г. О. Лукіна // Міжнародний журнал «Реабілітація та паліативна медицина». 2015. - № 2 (2). - С. 89-93.

5. Рега Н. І. Проблеми та перспективи викладання паліативної допомоги на етапах підготовки магістрів медсестринства / Н. І. Рега // Медична освіта. - № 4. 2012. - С. 126-129.

6. Робоча програма «Паліативна медицина» / розробник: С. О. Ястремська, ДВНЗ «Тернопільський державний медичний університет імені І. Я. Горбачевського МОЗ України», ННІ медсестринства. Освітньо-кваліфікаційний рівень: магістр. - Тернопіль, 2015. - 12 с.

7. Тематичний план і програма курсів удосконалення викладачів основ медсестринства / уклад. І. Я. Губенко, І. В. Радзієвська, Л. П. Бразалій, наук. консульт. Т. І. Чернишенко. - К., 2011. - 9 с.
2. Потрібно збільшити загальну кількість годин для вивчення цієї дисципліни і ввести в курс теми 3 надання паліативно-хоспісної допомоги дітям.

3. Доцільно проводити заняття з надання паліативно-хоспісної допомоги як у спеціалізованих відділеннях, де $є$ невиліковно хворі пацієнти (онкологічне, гематологічне, неврологічне тощо), так і в хоспісах.

8. Чернишенко Т. І. Підготовка медичних сестер з паліативної допомоги в Україні / Т. І. Чернишенко // Міжнародний журнал «Реабілітація та паліативна медицина». 2015. - № 2 (2). - С. 78-83.

9. Ястремська С. О. Роль медичних сестеру паліативній (хоспісній) допомозі / С. О. Ястремська, О. С. Усинська // Медсестринство. - 2011. - № 4. - С. 4-7.

10. Andrzejewska M. Pielęgniarstwo opieki paliatywnej w systemie kształcenia podyplomowego pielęgniarek / M. Andrzejewska, A. Janczura // Wyklady materialów Jubileuszowej Konferencji Naukowo - Szkoleniowej Opieki Paliatywnej i Zespołów Hospicyjnych. - Częstochowa, 2016. - S. 23-27.

11. Program kursu kwalifikacyjnego w dziedzinie pięliegniarstwa opieki paliatywnej dla pielęgniarek // M. Wiśniewski, A. Kaptacz, M. Krajnik, A. Panas. - Warszawa. 2015. - $44 \mathrm{~s}$.

12. Program kursu kwalifikacyjnego w dziedzinie pięliegniarstwa opieki długoterminowej dla pielęgniarek / E. Kądalska, L. Kimber-Dziwisz, I. Markiewicz, E. Stasiak. Warszawa. - 2015. - 73 s.

13. Program kursu kwalifikacyjnego w dziedzinie pięliegniarstwa opieki geriartycznrej dla pielęgniarek / B. Cegła, H. Doroszkiewicz, J. Pruszyński, M. Strugała. Warszawa. - 2015. - $58 \mathrm{~s}$.

14. Program kursu kwalifikacyjnego w dziedzinie pięliegniarstwa opieki onkologicznej dla pielęgniarek / M. Pasek, E. Czeczelewska, B. Kaźmierczak, M. Krajewski, D. Króliczewska ta inn. - Warszawa. - 2015. - 161 s. 